\title{
The English Needs of Occupational Safety and Health (OSH) Students at Tertiary Education Context: Students' Voices
}

\author{
$1^{\text {st }}$ Sri Haryati \\ Department of English Education \\ Sebelas Maret University \\ Surakarta, Indonesia \\ nafisahatiku@gmail.com
}

$4^{\text {th }}$ Hefy Suistyowati

Department of English Education

Sebelas Maret University

Surakarta, Indonesia

$\underline{\text { have_i@hotmail.com }}$

\author{
$2^{\text {nd }}$ Dewi Sri Wahyuni \\ Department of English Education \\ Sebelas Maret University \\ Surakarta, Indonesia \\ dewisriwahyuni17@yahoo.com
}

$3^{\text {rd }}$ Dewi Rochsantiningsih

Department of English Education

Sebelas Maret University

Surakarta, Indonesia

dewiroch@gmail.com

\author{
$5^{\text {th }}$ Gunarso Susilohadi \\ Department of English Education \\ Sebelas Maret University \\ Surakarta, Indonesia \\ gunarso_s@uns.ac.id
}

\begin{abstract}
One of the significant contributions of English for Specific Purposes (ESP) to the wider world of ELT is the development of thorough needs analysis as the cornerstone of ESP. It consisted of assessing the communicative needs of learners and particular strategy in achieving the learning goals for particular discipline. This article aim at investigating the learning needs and the target needs of Occupational Safety and Health (OSH) Diploma students in Indonesia. This research adopted mix method which use questionnaire and open-ended interview to obtain the data from 84 OSH students. The observation and document analysis are conducted to investigate the learners' need. The result of the research revealed that the students have high importance toward English for any reasons mainly to support their targeted job as safety officer aside from getting fluent in communication both in oral and written text. It became the major necessity in learning English at university level. Most students were put in intermediate level shows their lack in English learning. Dealing the students' wants, they mostly interested in learning OSH vocabularies. The responses of the participants indicated the need for exposure to an integrated English skill both in macro and micro level. This research implies that need analysis for particular field is necessary to be conducted for designing and developing the effective ESP instruction.
\end{abstract}

Keywords-need analysis, learners' needs, Occupational Safety and Health, ESP

\section{INTRODUCTION}

Teaching English for Specific Purpose (ESP) plays the significant roles for the last decades since English has become the contemporary global lingua franca. Later, the growing demand of English as the communication medium contributed rapidly around the world in which the popularity of ESP began. ESP, as defined by Harmer (1983, p. 1), is 'situations where the student has some specific reasons to learn a language. In addition, it is an approach to English language teaching in which all decisions as to content and methods employs at a specific domain for particular purpose (Hutchinson, 1987; Strevens, 1988; Celce-Murcia, 2001; Richards and Schmidt, 2010; Hossain, 2013; Otilia, 2015). ESP can be interpreted as education of English language. The stated definitions result in two basic characteristic of ESL in which it is based on particular context and learners specific needs. It is obvious that the main focus of ESP is to meet the learners' communication needs in particular field.

The distinctive characteristics of ESP, then, sets several objectives of teaching ESP namely (1) Proficiency objectives cover the mastery of the four language skills such as reading, writing, listening and speaking; (2) Knowledge objectives include the acquisition of linguistic and cultural information; (3) Linguistic knowledge objectives refer to language analysis and awareness of the systematic aspects of language while cultural knowledge objectives refer to the control of socio-cultural rules (mastery of the norms of society, values and orientations and also the ability to recognize culturally significant facts); (4) Affective objectives are about the development of positive feelings toward the subject of study and (5) Transfer objectives concern the ability to generalize from what has been learned in one situation or another (Stern, 1992, p. 5). Considering the objectives of ESP as well as its distinctive characteristic which focus on fulfilling learners' need in learning English, needs analysis is necessary to be conducted. It is strongly believed that ESP programs lean on needs analysis as a starting point for examining what kind of English learners need to learn (Handoyo, 2012). 
The initial analysis on learners' needs is the cornerstone in designing the effective ESP instructional design. West (1994, as cited in Cowling, 2007) defines needs as "what learners will be required to do with the foreign language in the target situation, and how learners might best master the target language during the period of training', ( $p$. 427). The analysis on students' needs, assist the educator to present the precise instructional design. Needs analysis then function as the consideration on which curriculum content, teaching materials and methods are constructed. It gives way to enhance the students' motivation and achievement as a result (Otilia, 2015) and assemble the data which will function as the foundation of developing a curriculum that will correspond to the needs of a specific group of learners (Munby, 1978; Richterich and Chancerel, 1987; Hutchinson and Waters, 1987; West, 1994; Brown, 1995; Dudley-Evans and St. John, 1998; Iwai, Kondo, Limm, Ray, Shimizu and Brown, 1999; Saragih, 2014).

Need analysis is goal-oriented, contextdependent and population-specific (Krohn, 2009). It gives the top priority to the goal accomplishment set by certain community for specific field including for Occupational Safety and Health (OSH). Currently, universities compete for having the OSH program to provide the professional safety officer. The massive establishment of OSH program by universities due to the raising demand for people who manage $\mathrm{OSH}$ within industries since the stipulation of government regulations which stated that the existence of safety officer is the basic requirement for industry (Minister of Manpower Regulation No. Per.05/Men/1996). The escalation of community awareness on safety and hygiene particularly in the workplace also triggers universities to establish the $\mathrm{OSH}$ program. The strategies arranged to produce qualified and professional safety officer and facilitate the students' learning like providing the slot for English teaching and learning.

Teaching English in tertiary education level is directed to bestow dual benefit for learners' academic purpose and their professional development particularly in OSH field (Kusumaningputri, 2010, p. 183). Those two benefits can be achieved by designing the qualified English teaching under ESP mode since learners begin learning the specific content dealing with OSH. The ideal ESP teaching reflecting the actual learners' needs in OSH field is necessary to be administered in instructional process. Consequently, the lesson planning, syllabus design, materials evaluation and development, and instructional design and assessment development have to adopt ESP principles.

Within these years, unfortunately, the English course in the OSH program was partially given in ESP mode. The materials of English in the OSH program tended to be General English that has different characteristics and purposes from ESP.
Consequently, the presents instructional process has not achieved the desired result and less addressing the learners" need both in academic purpose and future career. The absence of formal need analysis procedures in the initial teaching and learning process is strongly assumed as the cause of failure in meeting the students' needs. Then, it is an emergence to conduct need analysis for designing ESP for OSH students for several reasons: (1) the label of international reputable $\mathrm{OSH}$ program cannot be achieved when their outcome still act in survival English (General English); (2) the development of technology effects on the English vocabulary and context, especially in OSH; (3) the outcomes will have additional point when they have competencies in using English for specific purpose, that is $\mathrm{OSH}$; and (4) most companies are working and relating with other countries corporations, so it will be a necessity for OSH staffs to act and interact using English.

The periodic renewal on ESP design need to be conducted as the attempt to ensure that the course remains aligned with the learners' needs (Jackson, 2005). In quest of this issue, the role of needs analysis in any ESP curriculum should not be underestimated (Munby, 1978; Hutchinson \& Waters, 1987; Robinson, 1991; Flowerdew \& Peacock, 2001; Hamp-Lyons, 2001). On the contrary, it is acknowledged that "needs analysis is the cornerstone of ESP" and its proper application can result into a "focused course" (Dudley-Evans \& St John, 1998, p.121). Therefore, an attempt to bring ESP mode in $\mathrm{OSH}$ field initiated by need analysis as the cornerstone of ESP need to be made to investigate the learners' needs in target situation, the learners' wants for the materials, the learners' prior knowledge and the target learning, the preferred learning activities as well as the suggestion for better ESP course.

\section{RESEARCH METHOD}

The current study aims at presenting the wealth of data obtained on their perceived English needs in OSH field to support learners' academic life and future career. This study focused on the investigation of the learners' need in target situation, the learners' wants for the materials, the learners' prior knowledge and target learning, the desired learning activity as well as learners' suggestions for better ESP course. The participants of the study were 84 students of OSH consisting $52(62 \%)$ male and $32(38 \%)$ female students. Their age are varied around 20-22 years old. Mix method involving qualitative and quantitative research methods was adopted in these formal need analysis procedures. Questionnaire and interview was conducted to attain the data of the students' learning needs and target needs. The structures of the questions points out to the necessities, wants, lacks, input and procedures in teaching ESP for OSH students. Closed and open questions were made in the questionnaire. The semi 
structured interview was conducted to 18 students in attempt to achieve the meaningful insight of the learners needs of English in OSH context. The descriptive statistical method was used to analyze the data derived from questionnaire. The verbal data gotten from semi-structured interview were analyzed qualitatively adopting the model of Miles and Hubermen (1984) which underwent the complete procedures of data reduction, data display, conclusion drawing and verification. Triangulation of source and method is implemented as an attempt to reassure the validity of the data.

\section{FINDING AND DISCUSSION}

Hutchinson and Waters (1987:53) make a distinction between "target needs" and "learning needs". The target need refers to what the learner needs to do in the target situation and learning need refers to what the learner needs to do in order to learn (p.54). They further subcategorize target needs into (1) necessities that is what the learner has to know in order to function effectively in the target situation, (2) lacks refers to the discrepancy between necessity and what the learner already knows, (3) wants which defined as what the learner actually wants to learn or what they feel they need. The learner's "wants" may or may not conform those perceived by the teachers or course designers (p. 55-57).

\section{A. The Target Needs of OSH Students}

The learners, mostly, possess private necessities in learning English based on their priority. The result of the research revealed that almost half of the participants $(47.62 \%)$ state that English is importance for supporting their future career as safety officers particularly when working at multinational or international company. A quarter of the participants (25\%) expressed their necessity to learn English for educational purpose such as accessing the English literature about OSH. These necessities followed by the priority to learn English for merely getting the knowledge about English and its culture (17.86\%) and communicating with English speaking colleagues and widen the relation $(9.5 \%)$.

Dealing with the learners" "wants", the data revealed that almost third of the participants (33.33\%) wanted to understanding the English vocabularies while a quarter of the participants $(25.02 \%)$ eagered to communicate English well both written and oral. Some participants $(23.80 \%)$ wanted to comprehend various English text and the rest of them (17.85\%) wanted to to understand the English expression. The result of the interview pursed up the above finding. The participants admitted that they eagered to learn English to communicate well to foreign safety officer as well as performing English presentations. They also wanted to understand the English document in OSH field. Moreover, they expected being able to write the operational standard procedure (SOP) as well as English report at multinational even international company in which the OSH or HSE played the significant role as transcripted below:

P1 : Writing...as long as I know we have to write the SOP in English

P2 : I want to speak fluently to my English colleage. I don't want to look silly.

P3 : Some documents is written in English so we have to be able to understand it. It is a must to understant the document or we will know nothing.I really want to be able to comprehend the documents well.

P4 : I want to work in a big company...international one. I want to have presentation in English, writing report and many other things.And all done in English.

Regarding to the participants' prior competence, the third number of participants (31\%) put in beginner level where they were able to understand simple sentence and expression in daily life; more than half of the participants $(51.19 \%)$ positioned in intermediate level who able to comprehend various text and expression as well as finding the implicit information in it; and the rest participants (16.67\%) categorized into advanced learners who were able to understand and respond the complicated text.

\section{B. The Learning Needs of OSH Students}

The learners' needs are mapped based on the English skills at the macro level (listening, speaking, writing, as well as reading) and micro level (grammar, vocabulary and pronunciation). The demography of the learners' learning needs in terms of the input text as well as the salient learning activities are necessary to be uncover to obtain the obvious data about it.

The input, in this case, is the language that learners are exposed to that is communicative in nature. It is what the learners are paying attention to the language for the message(s) it contains. The input text preferred by the participants is presented in Table 1.

TABLE 1. The Input Text Input text Percentage

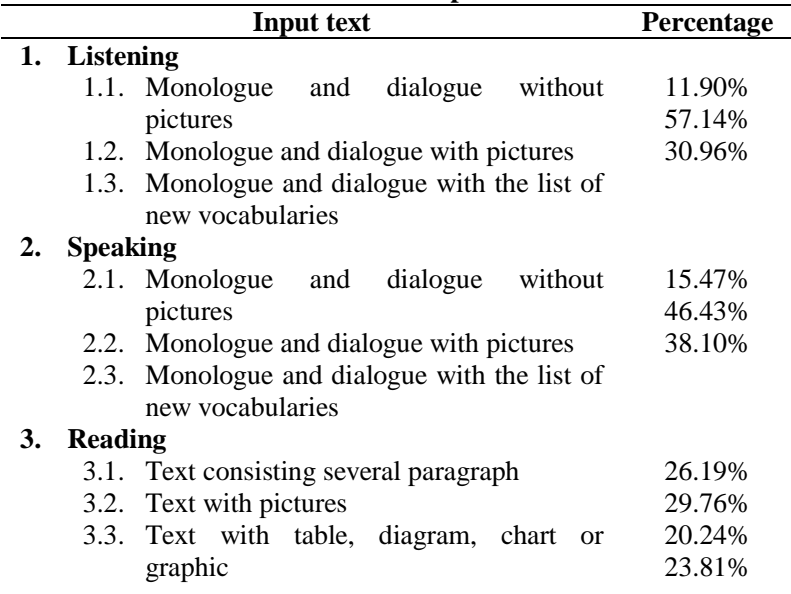


3.4. Text completed with the list of new

4. Writing

$$
\text { vocabularies }
$$

4.1. Sample of text being learnt

4.2. List of vocabularies related to the text

$33.33 \%$

4.3. Language features of the text

4.4. Pictures, graphic, chart or diagram

The length of the text which are still understandable for learners for each skill are varied. In listening, more than half of the students $(51.2 \%)$ preferred to have short text consisting less than 150 words. The medium text within 150-250 was chosen by some participants $(42.9 \%)$ while the rest $(5.9 \%)$ opted the long text (more than 250 words). Differ from listening, in speaking, the participants mostly preferred the medium length text within 150-250 words $(57.1 \%)$. The short text $(<150$ words $)$ was selected by $27.4 \%$ participants and others $(15.5 \%)$ chose the long text (>250 words). The tabulated data for the input of reading text showed that most participants $(64.3 \%)$ preferred the medium length text (150-250 words), around quarter of the participants (26.2\%) enjoyed the short text ( $<150$ words). Last, for writing text input, the participants preferred the medium length text within 150-250 words $(63.1 \%)$, the short text consisting 150-250 words $(26.2 \%)$ and long text consisting more than 250 words (10.7\%).

The data showed that the participants preferred to have the monologue and dialogue provided with pictures for their listening and speaking activities. In reading, the text completed with pictures can trigger them to learn while in writing, the sample of the text becomes the alternative input text. The desired length of the text directed to the usage of medium length text (150-250 words), except for listening.

\section{Learning Activities}

The adjustment of learning activities is needed in order to present extrinsic motivation in learning. It plays the significant roles to ensure the learners learning development and achievement. Table 2 presents the learning activities resulted from the need analysis.

TABLE 2. Activities in Learning Listening, Speaking, Reading, and Writing

\begin{tabular}{ll}
\hline \multicolumn{1}{c}{ Learning Activities } & Percentage \\
\hline 1. Listening & \\
1.1. Identifying the detail information of the & $28.57 \%$ \\
text & $26.19 \%$ \\
1.2. Identifying the content of the text & $19.05 \%$ \\
1.3. Completing the text \\
1.4. Identifying specific expressions of the text & $15.48 \%$ \\
1.5. Identifying the meaning and pronunciation & \\
2. Speaking & $10.71 \%$ \\
2.1. Practicing a model of dialogue or & $32.14 \%$ \\
$\quad$ monologue & $17.86 \%$ \\
2.2. Discussing a topic and giving opinion & \\
& related to the topics \\
2.3. Doing a role play & $17.86 \%$ \\
2.4. Making a dialogue then practicing it & $10.71 \%$ \\
2.5. Interviewing other friends related to the & $10.71 \%$
\end{tabular}

topics being

2.6. Discussed presenting a report, story,

$10.72 \%$ speech or discussion result

3. Reading

3.1. Reading a text to find the general idea of the text

3.2. Reading a text and answering the questions

3.3. Reading a text to find detail information

3.4. Discussing meaning of certain vocabulary in the context

3.5. Arranging jumbled paragraphs

3.6. Summarizing the content of the text

4. Writing

4.1. Writing the same text as the given model text based on the correct grammar and sentence structures

4.2. Arranging jumbled words to be a good sentence

4.3. Completing the missing words with own words

4.4. Correcting wrong sentence structures, spellings, and punctuations

4.5. Writing a conclusion

Writing a text based on pictures, tables, $13.21 \%$ diagrams, or graphics

Table 2 presents the preference learning activities for English macro skills in reading, writing, listening and speaking. Identifying the detail information of the text $(28.57 \%)$ in listening course positioned on the top rank activities chosen by learners. The dominant activity in speaking is practicing a model of dialogue or monologue which chosen by $32.14 \%$ participants. For reading, almost quarter of the whole participants $(24.77 \%)$ preferred to have reading a text to find the general idea of the text followed by reading a text and answering the questions with $23.01 \%$. For writing, writing the same text as the given model text based on the correct grammar and sentence structures was positioned as the top rank activity chosen by $22.64 \%$ participants followed by arranging jumbled words to be a good sentence with $21.23 \%$.

The learning activities in micro levels including vocabulary, grammar and pronunciation are varied. The resume of the learning activities for each micro skill is presented in table 3 .

TABLE 3. Activities in Learning Vocabulary, Grammar and Pronunciation

\begin{tabular}{|c|c|}
\hline Learning Activities & Percentage \\
\hline \multicolumn{2}{|l|}{ 1. Learning Vocabulary } \\
\hline $\begin{array}{l}\text { 1.1. Finding new vocabulary on a text and } \\
\text { finding the meaning on a dictionary }\end{array}$ & $21.34 \%$ \\
\hline $\begin{array}{l}\text { 1.2. Classifying new vocabulary on a table } \\
\text { then finding the meaning based on the } \\
\text { context }\end{array}$ & $20.08 \%$ \\
\hline 1.3. Matching words with to their meaning & $18.83 \%$ \\
\hline $\begin{array}{l}\text { 1.4. Searching the synonyms or antonyms } \\
\text { of words }\end{array}$ & $17.57 \%$ \\
\hline 1.5. Matching words with to the pictures & $13.39 \%$ \\
\hline $\begin{array}{l}\text { 1.6. Completing the paragraph using the } \\
\text { own word(s) }\end{array}$ & $8.79 \%$ \\
\hline
\end{tabular}


2. Learning Grammar

2.1. Doing grammar exercises

2.2. Completing the missing words on the text based on the context

2.3. Identifying and correcting the wrong sentence structures

2.4. memorizing sentence structure/grammar patterns

2.5. Writing sentences based on the given pattern

3. Learning Pronunciation

3.1. Pronouncing every sentence including the stress and intonation

3.2. Listening and repeating the pronunciation from the teacher

3.3. Searching the pronunciation on a dictionary

3.4. Reading aloud the pronunciation on a dictionary

The learning activities in teaching vocabulary divided into six learning activities which almost equally distributed. The data showed that finding new vocabulary on a text and finding the meaning on a dictionary is the top rank activities in teaching vocabulary $(21.34 \%)$. It was followed by $20.08 \%$ participants who preferred to classify new vocabulary on a table then finding the meaning based on the context. In learning grammar, doing grammar exercise obtained the significant percentage $(36.65 \%)$ which followed by completing the missing words on the text based on the context with $20.42 \%$. Lastly, in learning pronunciation, participants preferred to pronounce every sentence including the stress and intonation as the prominent learning activities preferred by $33.69 \%$ as the same as listening and repeating the pronunciation from the teacher.

Regarding the suggestions on ESP course, the verbal data derived from the open-ended question on 'what are the learners' proposals to improve the ESP instruction in OSH' resulted in some suggestions which categorized into ESP course and organizational issues.

TABLE 4. Suggestion for ESP Course

\begin{tabular}{|c|c|c|}
\hline & Categories & Frequency \\
\hline \multirow[t]{7}{*}{1.} & ESP Course & 438 \\
\hline & $\begin{array}{l}\text { 1.1. ESP under 'OSH' materials for } \\
\text { learners }\end{array}$ & 80 \\
\hline & $\begin{array}{l}\text { 1.2. Conducting need analysis in the } \\
\text { initial course }\end{array}$ & 76 \\
\hline & 1.3. Interactive ESP Course & 73 \\
\hline & $\begin{array}{l}\text { 1.4. Focus on specific and trending } \\
\text { issues }\end{array}$ & $\begin{array}{l}81 \\
56\end{array}$ \\
\hline & 1.5. Considering the learners' lack & 70 \\
\hline & $\begin{array}{l}\text { 1.6. Considering the different English } \\
\text { proficiency }\end{array}$ & \\
\hline \multirow[t]{6}{*}{2.} & Organizational Issues & 367 \\
\hline & $\begin{array}{l}\text { 2.1. ESP course in at least the first four } \\
\text { semester }\end{array}$ & 56 \\
\hline & 2.2. ESP trained lecture(s) & 78 \\
\hline & $\begin{array}{l}\text { 2.3. Small class ( }<20 \text { students) for ESP } \\
\text { class }\end{array}$ & 81 \\
\hline & $\begin{array}{l}\text { 2.4. Preparatory class for low level } \\
\text { students }\end{array}$ & 69 \\
\hline & $\begin{array}{l}\text { 2.5. Institutional support in providing } \\
\text { ESP course book }\end{array}$ & 83 \\
\hline
\end{tabular}

Regarding the suggestion for better ESP course, the result of semi-structured interview revealed almost the same result. The interview conducted to 20 students showed that for better ESP course, several efforts need to made as follows: (1) highlighting the ESP materials related to OSH context; (2) providing professional lecture(s) or tutor(s) for ESP classroom; (3) presenting communicative ESP teaching; (4) providing the ESP course book or handout; (5) administering need analysis in initial course; (6) facilitating learners different English proficiency; (7) acknowledging preferred method and learning styles.

The wealth data above illustrated some issues on ESP course for OSH students which can be used as the consideration to design better ESP course. The findings indicated that there was a highly specific ESP course to be implemented in the experimental needs-based syllabus document as part of the curriculum renewal process (Richards, 2001). Almost half of the participants $(47.62 \%)$ state that English is important for supporting their future career as safety officer particularly when working at multinational or international company. This fact was supported by the result of interview which referred to the implementation of ESP teaching and learning for $\mathrm{OSH}$ students. This finding are along with Chostelidou (2010) who reveal that the students coming from the specific discipline need for the development of a highly specific ESP language course with a clear focus on the target discipline.

It is acknowledged that the target group of learners despite the fact that they are all adults is far from what could be categorized as a homogeneous group (Mc Kay \& Tom, 1999) considering their previous learning experience and their level of linguistic competence. The heterogeneous learners influence the differences priority needs for learning then. The ranked showed the level of necessity of learning English, level of English proficiency, the preferred method and technique as well as the effective and efficient input text for their learning. These absolutely reflect learners' actual needs for learning specific subject based on their real situation and background.

Moreover, the responses of the participants indicate the need for exposure to an integrated skills approach; however, due to time constraints, it is inevitable to prioritize the practice provided in each skill (West, 1994 in Chostelidou, 2010). It is noted that the instructional design needs to highlight the practice on productive and receptive skill considering the clear input and students' need. The result of needs analysis then functioned as the consideration on which curriculum content, teaching materials and methods are constructed. It gives way to enhance the students' motivation and achievement as a result (Otilia, 2015). 


\section{CONCLUSION}

Each discipline requires the specific English teaching then including OSH. The doer as well as the key roles of the ESP specialist are described as being teacher, course designer, materials provider, collaborator (with subject specialist), researcher, and evaluator (Dudley-Evans and St John, 1998). Need analysis as the cornerstone of ESP, therefore, need to be conducted to meet the learner's need in learning and achieve the desired learning objectives. The formal need analysis procedure is urgently need to be administered as an effort to create the effective and efficient English teaching both in macro and micro level.

This study concerns on the learning needs covering the target needs and learning needs of OSH students. The result of the study showed that the participants possess the different needs in English but at the end sharing the same frame of ESP course. Most participants had a high expectation for learning English to support their future career as safety officer. Dealing with the input text, learners preferred to have the monologue and dialogue provided with pictures for their listening and speaking activities. In reading, the text completed with pictures can trigger the students to learn while in writing, the sample of the text becomes the alternative input text. The desired length of the text directed to the usage of medium length text, except for listening. The learning activities at the level of macro and micro skills are also varied. It reflects the preferred teaching activities which were expected to meet their needs of learning. Last, the suggestions for better ESP course covering the ESP course and organizational issues were made to provide correction for the ongoing subject.

The study implies that need analysis need to be administered in the initial of ESP course to depict the learners' learning needs for precisely meeting the learners needs and obtaining the learning goal. The result of the research, then, provides the strong consideration in designing the ESP materials or course book for OSH students yet. Further action responding the learners' suggestion about ESP course and organizational issues is also need to be made to create the better ESP course.

\section{ACKNOWLEDGMENTS}

The data were assembled from the OSH students coming from the some universities in Indonesia. We thank for the participants and our colleagues for their valuable input. We also thank to LPPM of Sebelas Maret University for the funding supports.

\section{REFERENCES}

[1] Brown, J. D. (1995). The elements of language curriculum: A systematic approach to program development. Boston: Heinle and Heinle.

[2] Celce-Murcia, M. (2001). Language teaching approaches: An overview. In M. Celce-Murcia (Ed.), TeachingEnglish as a Second or Foreign Language. Boston: Heinle and Heinle.
[3] Chostelidou, Dora. (2010). A Needs Analysis Approach to ESP Syllabus Design in Greek Tertiary Education: A Descriptive Account of Students' Needs. Procedia: Social and Behavioral Sciences 2 (2010) 4507-4512.

[4] Cowling, J. D. (2007). Needs analysis: Planning a syllabus for a series of intensive workplace courses at a leading Japanese company. English for Specific Purposes, 26, 426442.

[5] Dudley-Evans, T. \& St John, M.J. (1998). Developments in English for specific purposes. Cambridge: Cambridge University Press.

[6] Flowerdew, J., \& Peacock, M. (Eds.). (2001). Research perspectives on English for academic purposes. Cambridge: Cambridge University Press.

[7] Hamp-Lyons, L. (2001). English for academic purposes. In R. Carter \& D. Nunan, (Eds.), The Cambridge guide to Teaching English to Speakers of Other Languages (pp.126130). Cambridge: Cambridge University Press.

[8] Handoyo. 2012. Need Analysis and Curriculum Development in ESP. The European Journal of Applied Linguistics and TEFL.

[9] Harmer, Jeremy. (1983). The Practice of English Language Teaching, Third Edition, Longman.

[10] Hossain, M. (2013). ESP needs analysis for engineering students: A learner cantered approach. Presidency University, 2(2), 16-26.

[11] Hutchinson T., and Waters A., (1987). English for Specific Purposes: A Learning-Centred Approach, Cambridge: CUP, 1987

[12] Iwai, T., Kondo, K., Limm, S. J. D., Ray, E. G., Shimizu, H. \& Brown, J. D. (1999). Japanese language needs analysis.

[13] Jackson, J. (2005). An inter-university, cross-disciplinary analysis of business education: perceptions of business faculty in Hong Kong. English for Specific Purposes, 24 ,3, 293-306.

[14] Krohn, N. (2009): The Hebrew language needs of future conservative rabbis: A needs analysis. Journal of Jewish Education, 75, 258-289.

[15] Kusumaningputri. 2010. Need Analysis dalam Mata Kuliah English for Specific Purposes. Pengembangan pendidikan Vol. 8 No. 2, hal 324-331, Desember 2011

[16] Long, M. H. (2005). Second language needs analysis. Cambridge: Cambridge University Press.

[17] Mc Kay, H., \& Tom, A. (1999). Teaching adult second language learners. Cambridge: Cambridge University Press.

[18] Miles, M., \& Huberman, M. (1994). Qualitative data analysis. London: Sage Publications.

[19] Munby, J. (1978). Communicative syllabus design. Cambridge: Cambridge University Press.

[20] Munby, J. (1978). Communicative syllabus design: a sociolinguistic model for defining the content of purposespecific language programmers. Cambridge University Press.

[21] Otilia, S. M. (2015). Needs Analysis in English for Specific Purposes. Academica Brâncuşi Publisher, Economy Series, 1(2), 54-55.

[22] Minister of Manpower Regulation No. Per.05/Men/1996 on Management System of Occupational Safety and Health.

[23] Richards, J.C. \& Schmidt R. (2010). Longman Dictionary of Language Teaching and Applied Linguistics (4th Edition). London: Longman.

[24] Richards, J.C.(2001). Curriculum development in language teaching. Cambridge : Cambridge University Press.

[25] Richterich, R. \& Chancerel, J.L. (1987). Identifying the needs of adults learning a foreign language. Oxford: Prentice Hall.

[26] Robinson, P. 1991 ESP Today: a Practitioner's Guide. Hemel Hempstead: Prentice Hall International.

[27] Saragih, E. (2014). Designing ESP Materials for Nursing Students Based On Needs Analysis. International Journal of Linguistics, 6 (4), 59. 
[28] Strevens, P. , (1988). The Learner and the Teacher of ESP, Chamberlain Baumgardner 6: p 39-44, 1988

[29] West, R. (1994). Needs analysis in language teaching. Language Teaching, 27, 19. 